\title{
Western Australian Triplectidinae (Trichoptera: Leptoceridae): descriptions of the female of Triplectides niveipennis and larvae belonging to four genera
}

\author{
Rosalind M. St Clair \\ Environment Protection Authority, Freshwater Sciences, GPO Box 4395QQ, Melbourne 3001, Victoria, Australia \\ email: Ros.StClair@epa.vic.gov.au
}

\begin{abstract}
Larvae of Condocerus aptus, Notoperata tenax, Symphitoneuria wheeleri, Triplectides niveipennis, and Triplectides enthesis are described for the first time. The female of Triplectides niveipennis is also described for the first time. Variation in larvae and adults of Triplectides niveipennis is discussed, together with unusual characters in the larvae requiring redefinition of the genus. Minor changes to the generic descriptions of Condocerus, Notoperata and Symphitoneuria are also made.
\end{abstract}

\section{INTRODUCTION}

Leptoceridae is a major family of Trichoptera in Western Australia, being both diverse and common. The adult leptocerid fauna of Western Australia is moderately well known, due largely to the efforts of Arthur Neboiss (1982). The Monitoring River Health Program has resulted in large numbers of specimens of larvae available for study to augment distribution data based on adults. These data indicate three leptocerid faunas in Western Australia; one in the cooler wetter south west, one in the large rivers of the north, and one in the dry areas with little permanent fresh water. The southern fauna is largely endemic while the northern fauna is generally spread right across the north to Queensland and the arid area fauna is found throughout arid Australia.

Quite a deal of work remains to associate larvae with adults. Some Western Australian larvae were assigned to species by St Clair (2000) but not described. Most of these species are described here. Many other species were designated voucher numbers by St Clair (2000) as they could not be associated with adults and these species require the most study in Western Australia.

Larvae of Condocerus aptus, Notoperata tenax, Symphitoneuria wheeleri, Triplectides niveipennis, and Triplectides enthesis are described for the first time. The female of Triplectides niveipennis is also described for the first time. All of these species appear to be restricted to the southwestern part of the state, none reported from north of Perth. Exceptions are one record of $T$. enthesis from the far north and the extension of the range of $S$. wheeleri into South Australia.

Larvae and adults of Triplectides niveipennis are found to be variable but not enough adult or reared specimens are available to resolve problems at this time. The larvae are unusual and require redefinition of the genus.

Most specimens examined were collected during the Land and Water Resources Research Development Corporation funded Monitoring River Health Program and material is to be lodged in the Western Australian Museum. Site data for this material start with MUR for sites sampled by Murdoch University, CALM for Department of Conservation and Land Management, ECU for Edith Cowan University and UWA for the University of Western Australia. Numbers beginning with AV refer to specimens lodged in the Museum of Victoria. Numbers beginning with WAM refer to Western Australian Museum registration numbers. Some larvae examined were collected by Pierre Horwitz at Edith Cowan University as part of a program looking at peat areas. All other specimens are in the Western Australian Museum unless otherwise specified. All specimens listed under Material examined are larvae unless the male or female symbols are used to designate adults.

\section{Condocerus Neboiss}

This Australian genus is represented by two species only, very similar in appearance as larvae, with one from each side of the continent. The larvae of both species feed by attaching their case to something solid at the surface of the water in fast flow and lying with their long back legs outstretched to collect live or dead animals drifting past. This method of feeding is unique to this genus, although last instar larvae of Triplectides similis feed on similar food. 
As a result of associating Condocerus aptus, the larval generic description given by St Clair (1994) requires modification. The labrum is described as not having secondary setae but they are present in the species described here. This character is shared in Australia with Triplexa and Oecetis (St Clair, 1994) and with Notoperata tenax (see below).

\section{Condocerus aptus Neboiss Larva}

Figures 1-5, 32

\section{Diagnosis}

The front of the frontoclypeus and the labrum have secondary setae (Figures 1 and 2).

\section{Description}

Head (Figures 1, 2 and 3)

Width measured across, and including, the eyes about $0.7 \mathrm{~mm}$. Brown, paler laterally with lightly contrasting brown spots and contrasting yellow spot centrally towards anterior margin of frontoclypeus, sometimes with small paired paler spots anterior and/or posterior to this yellow spot; frontoclypeus widest on anterior margin; secondary setae present at front margin of the head and on labrum; ventral apotome narrow medially.

\section{Thorax (Figures 1 and 4)}

Pronotum mostly uniform brown; mesonotum with few slightly contrasting spots; metanotal sclerites brown; metasternum with row of setae and additional setae anterior to this row, most setae with small but prominent sclerite at base; legs uniform in colour, long spine-like setae present ventrally on fore- femora, tibiae and tarsi, mid femur, tibiae and tarsi and hind trochanters, femora, tibiae and tarsi (Figure 5).

\section{Abdomen}

Setae on first abdominal segment each with small but prominent sclerite at base; two pairs of short gills on segments 4 to 6 (rarely 3 to 6 ) only and additional gills at the tip of the abdomen; dorsal sclerite on abdominal segment 9 small and very pale, pigment spots obvious only occasionally; anal claws each with three small dorsal teeth.

\section{Body Length}

About $12 \mathrm{~mm}$.

\section{Case}

Made of small pieces of plant matter, often green, arranged to form tapering tube. Usually with additional long sections of detritus on sides and back appearing to act as stabilisers to help hold animal on the water surface and in current. Tube usually about 1.5 times length of larva but case often longer due to long "stabilisers." Identical to that of C. paludosus.

\section{Early instar laroae}

Pronotum with six or seven sclerites or hind legs with long spine-like setae and without pale setae on most segments allow identification of many earlier instar larvae.

\section{Remarks}

This species is extremely similar to $C$. paludosus from eastern Australia, differing only in the presence of secondary setae on the labrum and front of the frontoclypeus and slight differences in colour of the head.

\section{Material examined}

Western Australia: AV-0472 Foster Brook, North Dandalup, $32^{\circ} 29^{\prime} \mathrm{S} 116^{\circ} 03^{\prime} \mathrm{E}$ Coll. S. Bunn 19 September 1981, 4; Foster Brook, North Dandalup, $32^{\circ} 29^{\prime} \mathrm{S} 116^{\circ} 03^{\prime} \mathrm{E}$, in drift, Coll. S. Bunn 31 Jul. 1981, 3; ECU27, Blackwood River at Spearwood, $34^{\circ} 05^{\prime} 07^{\prime \prime} \mathrm{S} 115^{\circ} 18^{\prime} 47^{\prime \prime} \mathrm{E}, 10$ October 1994, Channel, 2 ; ECU21, Ellis Creek, 335' $59^{\prime \prime} \mathrm{S} 115^{\circ} 52^{\prime} 53^{\prime \prime} \mathrm{E}, 23$ September 1994, 1; MUR08, Dirk Brook, 32²6'39"S $116^{\circ} 01^{\prime} 34^{\prime \prime E}, 7$ September 1994, Macrophytes, 4, Channel, 1; MUR12, Little Dandelup River, 32 ${ }^{\circ} 35^{\prime} 31^{\prime \prime S} 116^{\circ} 01^{\prime} 34^{\prime \prime E}, 7$ September 1994, Macrophytes, 2, Channel, 2; MUR13, Big Brook, 32 $52^{\prime} 51^{\prime \prime S} 116^{\circ} 06^{\prime} 16^{\prime \prime E}, 8$ September 1994, Channel,

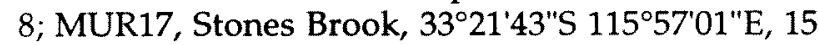
September 1994 Riffle, 1; MUR18, Ernest River,

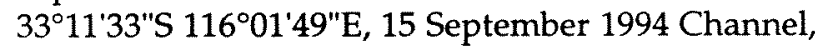
15; MUR23, Harvey River at Hoffmans Mill, $33^{\circ} 04^{\prime} 41^{\prime \prime S} 116^{\circ} 06^{\prime} 56^{\prime \prime E}, 9$ September 1994, Macrophytes, 35, Channel, 4; MUR24, Harvey River Tributary, $33^{\circ} 01^{\prime} 10^{\prime \prime} \mathrm{S} 116^{\circ} 05^{\prime} 37^{\prime \prime} \mathrm{E}, 9$ Sep 1994 , Channel, 2; UWA01, Beedelup Brook at Steep Road, $34^{\circ} 24^{\prime} 47^{\prime \prime S} 115^{\circ} 52^{\prime} 29^{\prime \prime} \mathrm{E}, 15$ October 1994 Channel, 2, Macrophytes, 4; UWA04, Fly Brook at Alamein

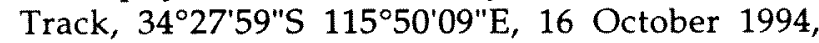
Macrophytes, 16; UWA08, Treen Brook, track off

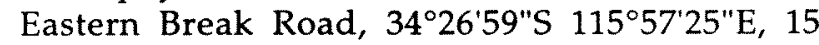
October 1994, Organics, 1; UWA10, Un-named stream on Lewis Road, $34^{\circ} 35^{\prime} 32^{\prime \prime S} 115^{\circ} 54^{\prime} 46^{\prime \prime} \mathrm{E}$, Macrophytes, 45; UWA13, East Brook at Raspy Road, $34^{\circ} 27^{\prime} 55^{\prime \prime} \mathrm{S} 116^{\circ} 02^{\prime} 00^{\prime \prime E}$. 13 October 1994, Macrophytes, 3; UWA17, Un-named tributary at Marron Rd, 34 ${ }^{\circ} 48^{\prime} 01^{\prime \prime} S 116^{\circ} 21^{\prime 2} 27^{\prime \prime} \mathrm{E}, 12$ October 1994 Macrophytes, 1; UWA18, Shannon River at Nelson Road, $34^{\circ} 42^{\prime} 24^{\prime \prime} \mathrm{S} 116^{\circ} 21^{\prime} 27^{\prime \prime} \mathrm{E}, 11$ October 1994 , Macrophytes, 5; UWA20, Forth River at Chesapeake Road, 34 ${ }^{\circ} 51^{\prime} 52^{\prime \prime} \mathrm{S} 116^{\circ} 25^{\prime} 29^{\prime \prime} \mathrm{E}, 12$ October 1994, 24; UWA22, Tributary of Weld River, $34^{\circ} 41^{\prime} 23^{\prime \prime S}$ $116^{\circ} 31^{\prime} 15^{\prime \prime E}, 9$ October 1994, Macrophytes, 13;

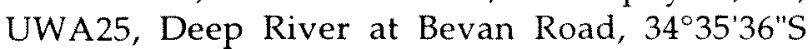
$116^{\circ} 33^{\prime} 06^{\prime \prime}$ E, 9 October 1994, Macrophytes, 1; 

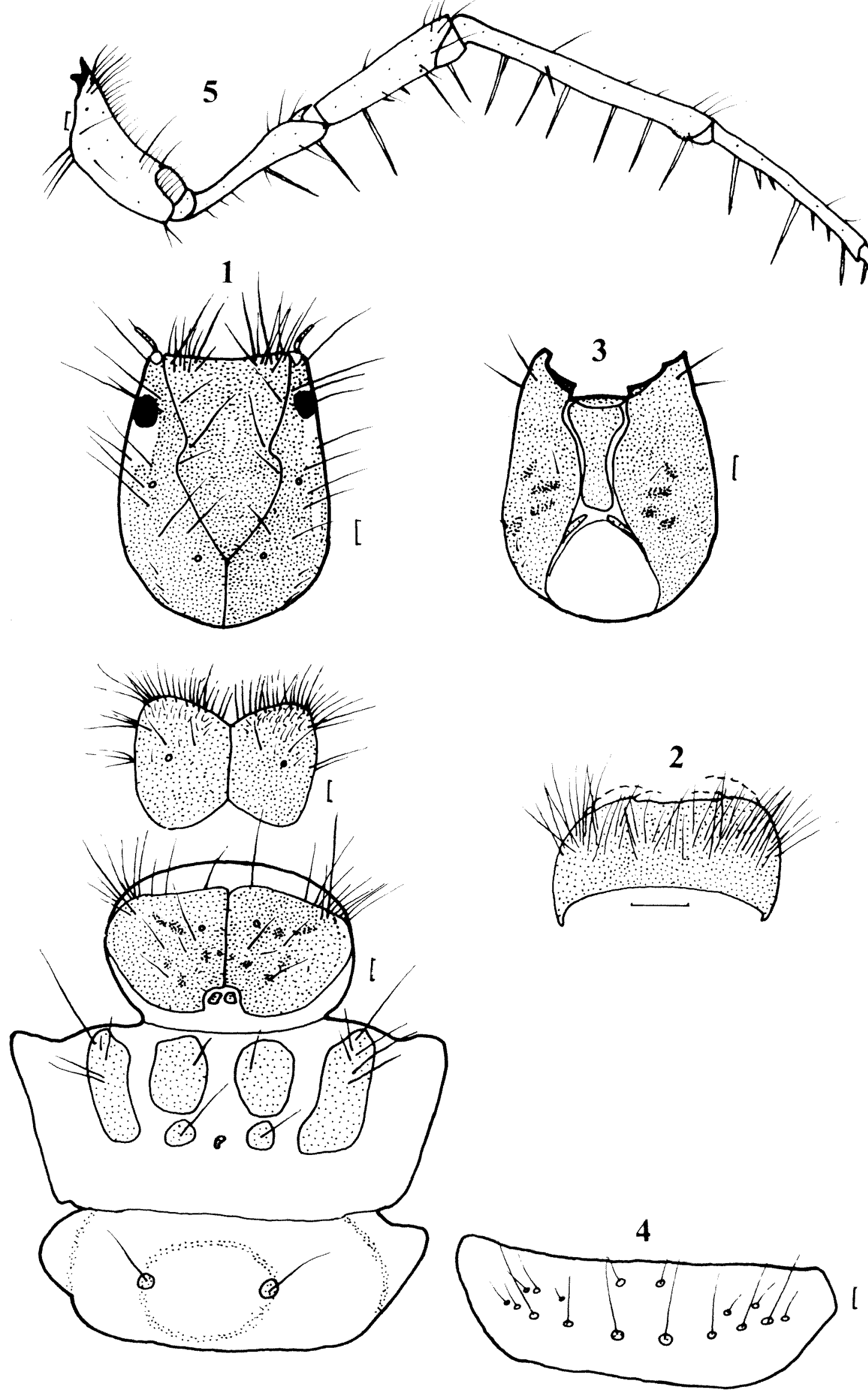

Figures 1-5 Condocerus aptus larva, specimen vial AV-0472: 1, head and thorax dorsal; 2, labrum dorsal; 3, head ventral; 4 , metasternum; 5 , right hind leg posterior. All scale bars $0.1 \mathrm{~mm}$ 
UWA27, Bell Brook at track of South Western Highway, $34^{\circ} 58^{\prime} 25^{\prime \prime S} 116^{\circ} 35^{\prime} 51^{\prime \prime} \mathrm{E}, 30$ September 1994, Macrophytes, 1; UWA29, Walpole River off Plain Road, 34'57'40"S 116 $42^{\prime} 17^{\prime \prime}$ E, 8 October 1994, Macrophytes, 40; UWA30, Nile Creek at Break Road, 3450'41'S 117 02'37'E, 29 September 1994, Macrophytes, 1; UWA32, Styx River, $0.5 \mathrm{~km}$ up from Styx Road, 34 $52^{\prime} 57^{\prime \prime S} 117^{\circ} 08^{\prime} 21^{\prime \prime E}, 27$ September 1994, Macrophytes, 2; UWA34, Denmark River at Granite Road, $34^{\circ} 49^{\prime} 47^{\prime S} 117^{\circ} 15^{\prime} 02^{\prime \prime E}, 28$ September 1994, Macrophytes, 6.

\section{Habitat and Distribution}

Western Australia, confined to areas with permanent flow in the Southwest (Figure 32).

\section{Notoperata Neboiss}

This is a genus of five described species, all from Australia. I recognise larvae from a further two species (St Clair, 2000). At least three species occur in Western Australia. The description here of the larva of Notoperata tenax is the first of the larva of a species from Western Australia, the other species in this state not having been associated with the adult. A key separating the larvae of the species was provided by St Clair (2000).

The larval generic description given by St Clair (1994) requires modification in that the labrum of the species described here has nine pairs of setae dorsally along the mid section of the labrum. In Australia, as noted above, secondary setae are also present on labra of larvae of Condocerus, Triplexa and Oecetis although many more additional setae are present on the labra of these three genera than on this species of Notoperata.

\section{Notoperata tenax Neboiss Larva \\ Figures 6-9, 33}

\section{Diagnosis}

The labrum has a transverse medial line of nine pairs of setae (Figure 6), there are comparatively long extensions on anterior pronotal corners (Figure 6) and about 8 metasternal setae are present (Figure 8).

\section{Description}

Head (Figures 6 and 7)

Width measured across, and including, the eyes $7.2 \mathrm{~mm}$. Dark brown with paler spots; frontoclypeus long, widest on anterior margin; ventral apotome tapering.

\section{Thorax (Figures 6 and 8)}

Pronotum dark brown with paler spots, anterior margin scalloped, anterolateral corner much extended and cut away laterally; mesonotum dark brown with paler spots; metanotum pale with dark patches, lateral sclerites about $1 / 3-1 / 2$ length of segment; metasternum with about eight scattered setae and no sclerites; legs with darker bands, with some moderately long spine-like setae ventrally and long setae (Figure 9).

\section{Abdomen}

Gills single filaments on segments 2 to 4 dorsally, 2 to 3 or 5 laterally and 2 to 5 or 6 ventrally; tergite 9 very pale and comparatively large; anal claw with two dorsal teeth.

\section{Body Length \\ About $9 \mathrm{~mm}$.}

Case

Tubular, made of detritus.

\section{Remarks}

This species shares with the two species already described as larvae (St Clair, 1994) the anterolateral pronotal extensions and cutaway anterolateral pronotal margin. It differs markedly in the presence of a line of nine pairs of long setae on the labrum, which is unique in the Australian Leptoceridae but very similar to several genera of Calamoceratidae which have eight pairs of setae.

\section{Material examined}

Western Australia: Lake Smith, Donelly Catchment, $34^{\circ} 25^{\prime} 48^{\prime \prime S} 15^{\circ} 43^{\prime} 36^{\prime \prime} \mathrm{E}, \mathrm{FBA}$, January 1995, P. Horwitz, 1, WAM 27555; ECU5, Hamersley River at Tallawarra, $33^{\circ} 43^{\prime} 43^{\prime \prime S} 121^{\circ} 14^{\prime} 48^{\prime \prime}, 2$ January 1995, Macrophytes, 2; ECU32, Margaret River at Canebrake Road, 33 ${ }^{\circ} 52^{\prime} 35^{\prime \prime S} 115^{\circ} 17^{\prime} 23^{\prime \prime}, 17$ January 1995, Macrophytes, 1; MUR08, Dirk Brook, $32^{\circ} 26^{\prime} 39^{\prime \prime} \mathrm{S} 116^{\circ} 01^{\prime} 34^{\prime \prime} \mathrm{E}, 7$ September 1994 , Macrophytes, 2, Channel, 4; UWA01, Beedelup Brook at Steep Road, $34^{\circ} 24^{\prime} 47^{\prime \prime S} 115^{\circ} 52^{\prime} 29^{\prime \prime}$, 28 January 1995, Organics, 1; UWA15, Shannon River at Curtin 4 Road, $34^{\circ} 34^{\prime} 12^{\prime \prime S} 116^{\circ} 25^{\prime} 49^{\prime \prime} \mathrm{E}, 18$ January 1995, Macrophytes, 1; UWA08, Treen Brook, track off Eastern Break Road, 34²6 $59^{\prime \prime S} 115^{\circ} 57^{\prime} 25^{\prime \prime} \mathrm{E}, 15$ October 1994, Channel, 2.

\section{Habitat and Distribution}

Rivers and lakes in southwestern Western Australia (Figure 32). Possibly cool waters only. The far eastern site, ECU5, seems anomalous but I have not had the opportunity to check it.

\section{Symphitoneuria Ulmer}

The genus Symphitoneuria is known from three Australian species, S. exigua described from 


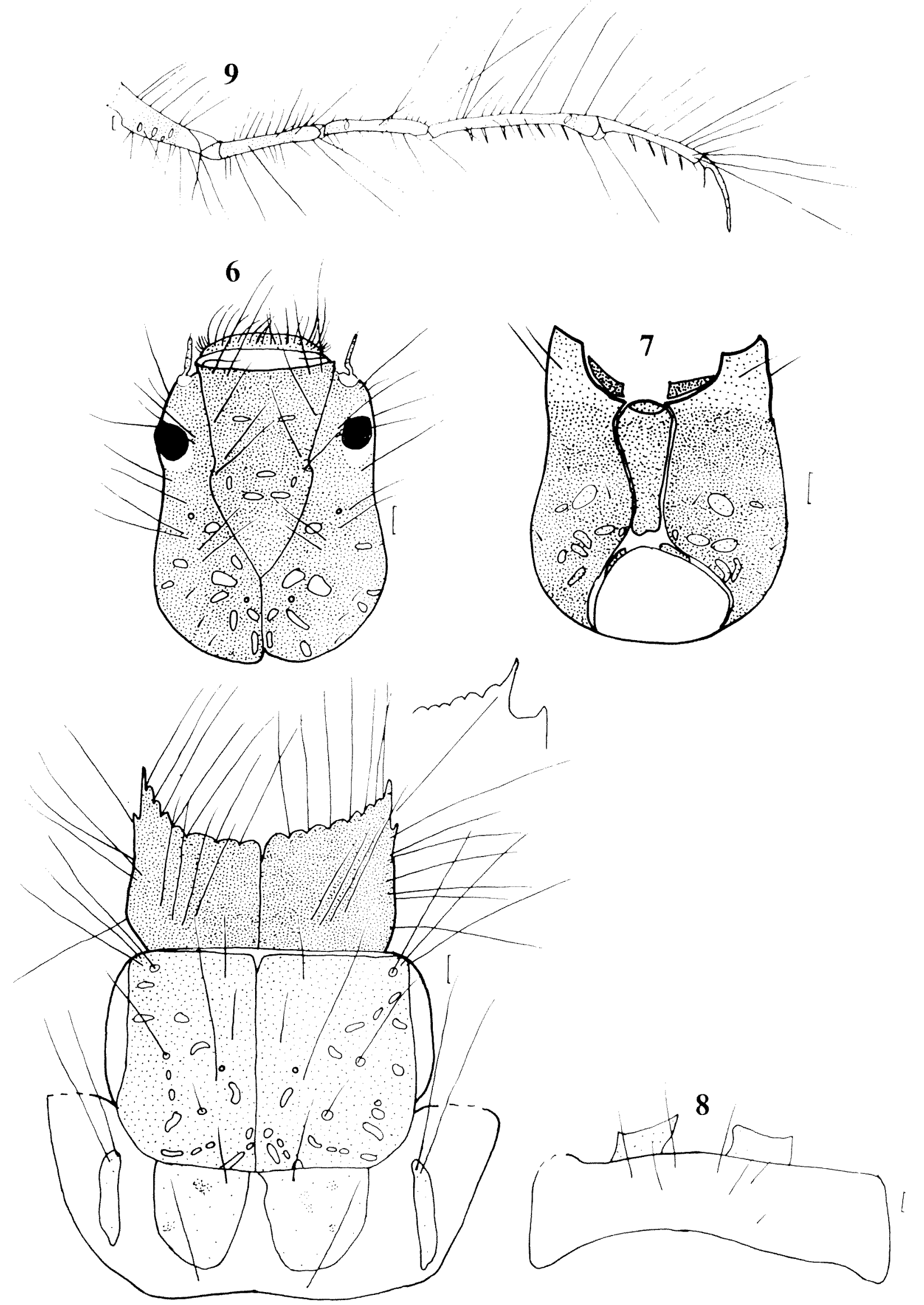

Figures 6-9 Notoperata tenax larva WAM 27555: 6, head and thorax dorsal, showing pronotal anterolateral corner detail; 7 , head ventral; 8 , metasternum and mesosternal sclerites; 9 , right hind leg posterior. All scale bars $0.1 \mathrm{~mm}$. 
Queensland, S. opposita described from Victoria and recently found in the Mt Kosciuszko region of NSW, and S. wheeleri described from Western Australia and recently found to occur in South Australia as well. The larva of $S$. opposita was described by $S t$ Clair (1994). The larva of $S$. wheeleri is described here. A photograph of the larvae of a third species was figured by St Clair (2000) as Symphitoneuria sp. $A V 1$. This may be the larva of $S$. exigua. If so, this species occurs from North Queensland to mid New South Wales.

The larval generic description given by St Clair (1994) requires minor modification as this species does not have a long extension on the pronotal anterolateral corner.

\section{Symphitoneuria wheeleri Banks Larva}

Figures $10-12,32$

\section{Diagnosis}

The pronotal anterior margin is only lightly scalloped, the pronotal anterolateral corner only slightly elongate and angled or scooped out laterally and the mesonotum is much paler than pronotum (Figure 10).

\section{Description}

Head (Figures 10 and 11)

Width measured across, and including, the eyes $0.73 \mathrm{~mm}$. Brown with pale spots; antennae about $1 / 3$ length of the frontoclypeus on its anterior margin; ventral apotome tapering slightly.

\section{Thorax (Figures 10 and 11)}

Pronotum brown with paler spots; mesonotum paler with dark spots; metanotal sclerites pale with dark spots, sometimes with a small sclerite at base of each long posterior seta; metasternum with numerous setae, without metasternal sclerite; legs sometimes with darker bands, claws dark brown and contrasting with rest of leg segments, and hind legs with moderately long spine-like setae and most setae dorsal (Figure 12).

\section{Abdomen}

Gills single filaments on segments 1 to 8 or 2 to 8 , 2 to 5 or 7 laterally; lateral line moderately short and pale or dark; tergite 9 very pale, not visible; brown spots on lateral sclerites, rest very pale; anal claws each with one dorsal tooth.

\section{Body Length \\ $14 \mathrm{~mm}$.}

\section{Case}

Tubular, made of coarse sand grains or detritus.
Early instar larvae

Recognised by case (if sand grains used), small metanotal sclerites, divided hind tibiae and only pale basal sclerites on the metasternum.

\section{Remarks}

Distribution can be used to identify the three Australian species, however, both S. opposita and S. wheeleri occur in South Australia, although probably in different areas. Symphitoneuria wheeleri is readily identified by the relatively unmodified front margin and anterolateral corners of the pronotum and by the colour contrast between the pro- and mesonota.

\section{Material examined}

Western Australia: AV-0469, Lake Preston, salty dune lake S of Perth, March 1972, Coll. P. Zwick, 5; ECU2, Lort River at Grass Patch Road, 33 ${ }^{\circ} 45^{\prime} 59^{\prime \prime} \mathrm{S}$ 119³6'59", 5 August 1995, 1; ECU5, Hamersley River at Tallawarra, $33^{\circ} 43^{\prime} 43^{\prime \prime S} 121^{\circ} 14^{\prime} 48^{\prime \prime}, 5$ August 1995, 1; ECU7, Hamersley River at Old Ongerup

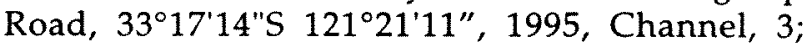
ECU8, Fitzgerald River at Quoin Head Track, 3353'16"S 119'51'59", 6 August 1995, Macrophytes, 7; ECU12, St Mary River Estuary, 3409'34"S 119³2'52", 9 August 1995, Channel, 5; ECU13, Gairdner Creek at Monkey Rock Road, 34 00'39"S $119^{\circ} 03^{\prime} 37^{\prime \prime}, 5$ January 1995, Channel, 1; ECU15, Gairdner River at Devil Bend Road, $34^{\circ} 13^{\prime} 07^{\prime \prime} \mathrm{S}$ $119^{\circ} 15^{\prime} 57^{\prime \prime}, 9$ August 1995, Riffle, 3; ECU46, Channel, 4. South Australia: Saline pool, Coll. Ghassemzodeh, February 1995, 4, lodged in the South Australian Museum.

\section{Habitat and Distribution}

This species is found in lakes and rivers in southern Western Australia (Figure 32) and South Australia. This species is usually found in saline waters and its distribution may be increasing with increasing salinity.

\section{Triplectides Kolenati}

Triplectides is one of the larger genera in Australia, both in number of species and the size of the larvae. It also occurs in South America and Asia. Only three species are known from south-western Western Australia, although Triplectides niveipennis is either polymorphic or two closely related species. Two, $T$. niveipennis and T. enthesis, are endemic to the Southwest while the third, T. australis, is one of very few caddis species found throughout the continent. Triplectides niveipennis was associated with the adult recently and is described here. The larva of $T$. enthesis is yet to be associated but the larva designated to Triplectides sp. AV 1(see St Clair, 2000 ) is found in appropriate habitats and is almost certainly the larva of $T$. enthesis. It is described here 


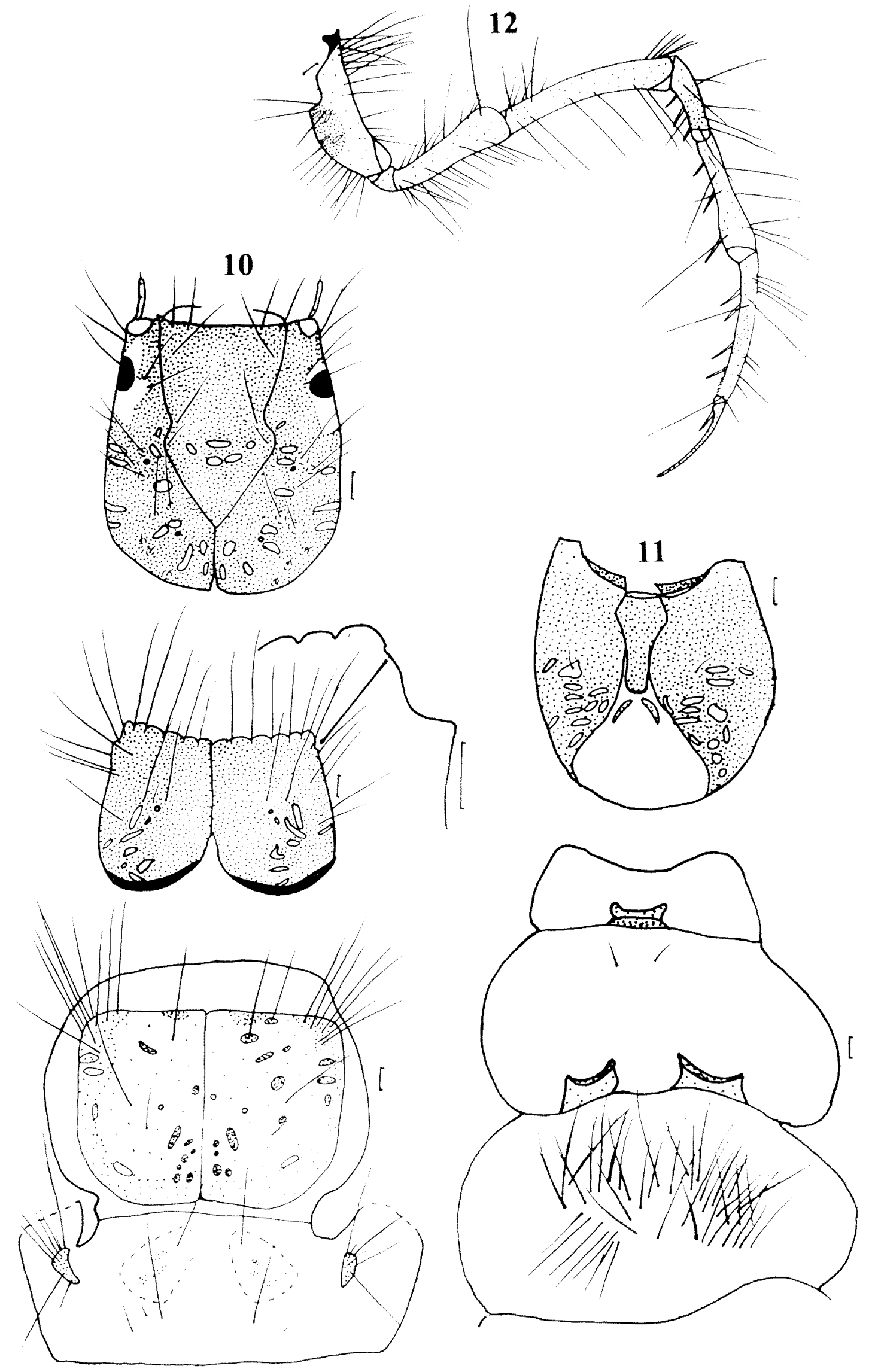

Figures 10-12 Symphitoneuria wheeleri larva, specimen vial AV-0468: 10, head and thorax dorsal, showing pronotal anterolateral comer detail; 11, head and thorax ventral; 12, right hind leg posterior. All scale bars 0.1 $\mathrm{mm}$. 
as the larva of $T$. enthesis. The larva of $T$. australis was described and figured by St Clair (1994) and figured in part by St Clair (2000).

The generic description given by St Clair (1994) requires amendment following the association of Triplectides niveipennis. The antennae of all larval Triplectides are short, one eighth to one quarter the length of the frontoclypeus at its front margin. This character was the only one that completely defines the genus but now the larva of $T$. niveipennis is known to have long antennae. The larva of $T$. niveipennis are also unique in the genus in their tendency for each lateral metanotal sclerite to divide into 2 sclerites and in having a long twopronged extension on the pronotal margin on each side near the anterolateral corners. The full implications of these unusual characters are discussed below.

\section{Key to final instar Triplectides larvae of south- western Western Australia}

1 Three large yellow spots on frontoclypeus, one in posterior tip and one on each side of constriction; metasternum with about 4 small sclerites, usually associated with pairs of setae; final instar larva with only slight scalloping on front margin of pronotum; ventral apotome fairly broad posteriorly $(\mathrm{St}$ Clair 1994, 2000) ................ Triplectides australis

- No large spots on frontoclypeus (Figures 19, 25); metasternum without sclerites or with extremely small sclerites at base of single setae (Figures 23, 27); two-pronged extension on front margin of pronotum on each side, near the anterolateral corner, which may be long to very short (Figures 20, 25); ventral apotome tapering but not to point (Figures 22, 26) ......................... Triplectides niveipennis

- No large spots on frontoclypeus (Figure 29); metasternum with large but pale central sclerite (Figure 30); final instar larvae with only light scalloping on front margin (Figure 29); ventral apotome strongly tapering to point (Figure 30) ................ Triplectides enthesis

\section{Triplectides niveipennis Mosely \\ Figures 13-28, 34}

Triplectides niveipennis is either a polymorphic species or a species complex but too few adult or reared specimens are available at present to resolve this issue. The species is unique in the Australian Leptoceridae fauna in that it has two distinct larval colour morphs. These two morphs are separated and designated different Australian Voucher species numbers for the larvae, Triplectides sp. AV 20 and Triplectides sp. AV 21 (see St Clair, 2000).
Triplectides sp. AV 20 has dark brown on the head dorsally, in a transverse band across the pronotum and on mid and hind-leg segments except coxae and Triplectides sp. AV 21 is a much more uniform colour. Triplectides sp. AV 20 appears to have longer and more slender legs although ratios are fairly similar (compare with the photograph, Figure 124, of the two larval types by St Clair, 2000). The length of the projections on the pronotum varies greatly, with short, intermediate, and long variations occurring in Triplectides sp. AV 21. Only long projections have been seen in Triplectides sp. AV 20 , but fewer specimens have been examined. Both larval types and the full variation of the length of the pronotal projection in Triplectides sp. AV 21 occur together at some localities.

Variation also occurs in the adults. Males reared from Triplectides sp. AV 20 larvae have pale hind wings but males reared from Triplectides sp. AV 21 larvae have white hind wings. Slight variation in the shape of segment $X$ and the preanal appendages occurs, possibly related to larval colour differences but not enough specimens are associated to confirm this. The wings of females reared from Triplectides sp. AV 21 are pale and not white, but no female has been reared from a Triplectides sp. AV 20 larva for comparison. The adult males reared from Triplectides sp. AV 21 larvae best fit the original description.

\section{Position of Triplectides niveipennis in the genus}

Based on characteristics of the male, Triplectides niveipennis was placed in a group of its own by Morse and Neboiss (1982) but they noted similarities with Triplectides enthesis. In that publication, the authors noted that "surely the discovery of the female for this species will shed light on its historical relationships." Characters of the female also indicates this species has some similarity with $T$. enthesis but does not clearly fit into any particular group. Morse and Neboiss (1982) note the female of $T$. enthesis has vertical crescentic carina on upper lateral surface of segment IX relatively closer to anterior edge of segment than in other Triplectides species and this is true also for $T$. niveipennis.

Only one character defines the genus Triplectides in the larval stage and that is the presence of short antennae on the front margin of the head capsule. This character is shared with some Leptocerinae larvae (eg. some Oecetis and Ceraclea) but the presence of metanotal sclerites in Triplectides is sufficient to separate its species from the leptocerine exceptions. While there are one or two characters that are found only in Triplectides, they are not present in all species or all specimens and so cannot be used alone to diagnose the genus. As Triplectides niveipennis larvae have long antennae, this leaves the genus not uniquely defined for the larval stage 

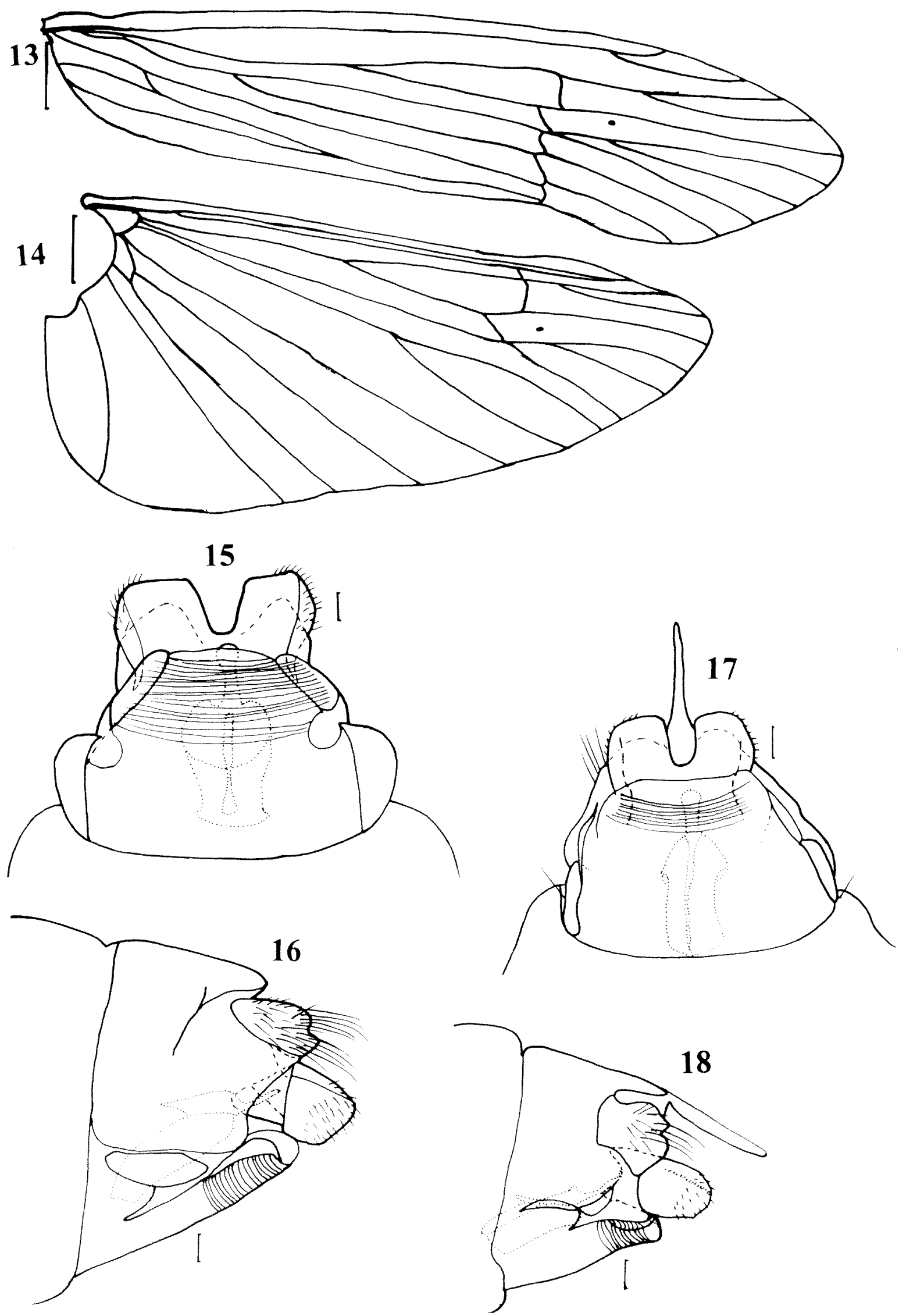

Figures 13-18 Triplectides niveipennis adult female WAM 27557: 13, right fore wing dorsal; 14, right hind wing dorsal; 15, last abdominal segment ventral; 16, last abdominal segment lateral. Adult female WAM 27556: 17, last abdominal segments ventral, showing long transparent process; 18, last abdominal segments lateral, showing long transparent process. Scale bars for figures 13 and $141.0 \mathrm{~mm}$, all other scale bars $0.1 \mathrm{~mm}$. 
and confirms this species' uniqueness within the genus.

The larva of $T$. niveipennis has a sclerite posteriorly on the metanotum, although often divided into two sclerites. This sclerite is only found in Triplectides and helps separate it from larvae of its related genera. Unfortunately it is only found in about half the species. The case used by $T$. niveipennis is always a piece of stick or stem hollowed out by the larva. This case type is only found in Triplectides and is used by most, if not all, of the species in the genus but not all individuals of many species. The presence of the posterior metanotal sclerite and the case type clearly place this species in Triplectides.

Several larvae of $T$. enthesis have the lateral metanotal sclerite divided into two. This also occurs frequently in larvae of the three species of Lectrides but has not been seen in other genera or other species of Triplectides.

The long antennae, the frequent division of the lateral sclerites on the metanotum and two pronged processes on the front margin of the pronotum combine to give the larvae of this species a unique place within the genus and do not align it within any species group. The arrangement of metasternal sclerites and setae is also unusual but there is more variation within the species groups in this character. The larva shows no particular similarity with the larva of Triplectides enthesis.

\section{Adult}

\section{Description}

Female: Adult females similar to males in having dark segments distally on fore- and mid legs and palps. Forewings (Figure 13) with sectoral crossvein almost straight; posterior vein forming discoidal cell almost straight, $\mathrm{S} 4$ longer than in male forewing. Hind wings (figure 14) pale but not white; not as enlarged and lacking additional veins present in hind wing of described male (Morse and Neboiss 1982). (The two males reared to the winged stage also lack these additional veins in the hind wing, although the wing is still very broadened).

Genitalia: (Figures 15 to 18) dorsal setose lobes short; each without sensilla bearing process, although very small pale process is present on the margin of the setose lobe (giving a bilobed appearance) but without sensilla; lamellae moderately long, each with distinct longitudinal ridge dividing it into two sections almost as long as each other and with surfaces at right angles to each other (thus appearing broad in both lateral and dorsal views), with short setae but apparently without striae. Spermathecal sclerite with long rounded anterior extension. Spermathecal sclerite most similar to that of $T$. elongatus but with some similarities also to $T$. australis and $T$. enthesis. One female has a long membranous projection extending from segment IX dorsally (Figures 17 and 18), but such process was much shorter in one other specimen and completely absent in the remaining specimen.

\section{Larva}

\section{Diagnosis}

The antennae are long, at least $1 / 4$ the width of the frontoclypeus on the anterior margin (rare specimens with shorter antennae) (Figure 19); the pronotal anterior margin is lightly scalloped and with two long or short two-pronged extensions and the anterolateral margin is rounded (Figure 20); the metanotum has five sclerites but long lateral and/ or posterior sclerites may be divided into two, giving as many as eight sclerites (Figure 21). Some or all of these sclerites may be very pale.

\section{Description}

\section{Triplectides sp. AV 20}

Head (Figures 19 and 22)

Width measured across, and including, the eyes $0.93 \mathrm{~mm}$. Orange with triangular dark patch on top of the head extending almost to back of head, ventrally pale with numerous very pale spots in bands.

\section{Thorax}

Pronotum orange anteriorly and posteriorly, brown transverse band medially, with medial prong of two-pronged process longer than lateral (Figure 20); prosternal sclerite comparatively large (Figure 23); hind legs very long and slender (Figure 24); mid and hind legs each with coxa orange, rest of leg dark brown; foreleg orange. (This species was originally designated Leptoceridae Genus B sp. AV 3.)

\section{Triplectides sp. AV 21}

Head (Figures 25 and 26)

Width measured across, and including, the eyes $0.88-1.01 \mathrm{~mm}$ (2 specimens). Dark red-brown with paler spots.

\section{Thorax (Figures 25 and 27)}

Pronotum dark red-brown with paler spots; mesonotum brown; metanotum pale brown; hind legs pale brown, uniform in colour (Figure 28). (This species was originally designated Leptoceridae Genus B spp. AV 1 and 2.)

\section{Description applying to both larval types}

Head (Figures 19, 22, 25 and 26)

All setae on head comparatively pale; 


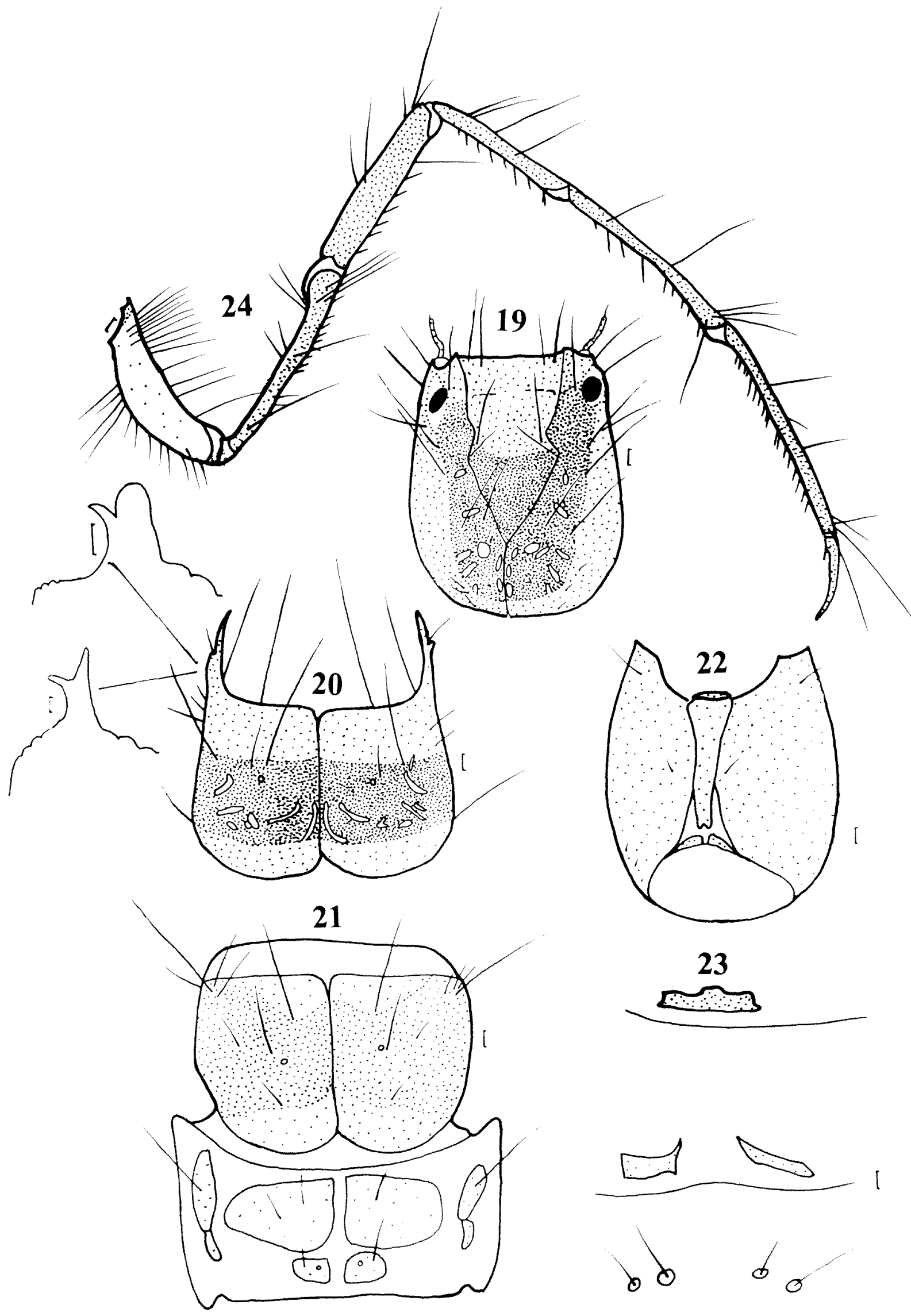

Figures 19-24 Triplectides niveipennis sp. AV 20 larva, WAM 27558: 19, head dorsal; 20, pronotum, dorsal, showing some variation in anterolateral corner detail; 21, meso- and metanota dorsal; 22, head, ventral; 23, pro-, meso-, and metasternal sclerites; 24, right hind leg posterior. All scale bars $0.1 \mathrm{~mm}$. 

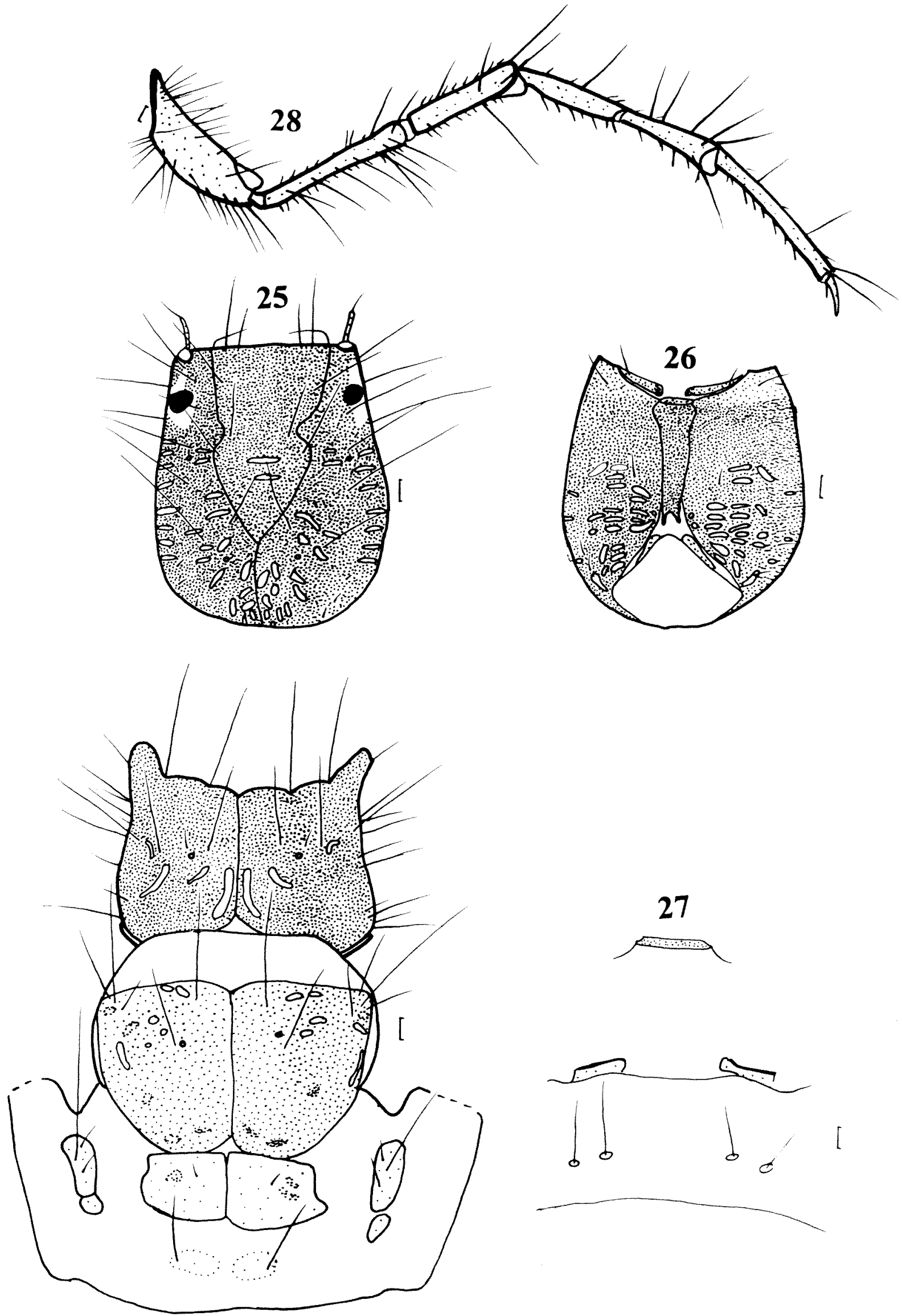

27
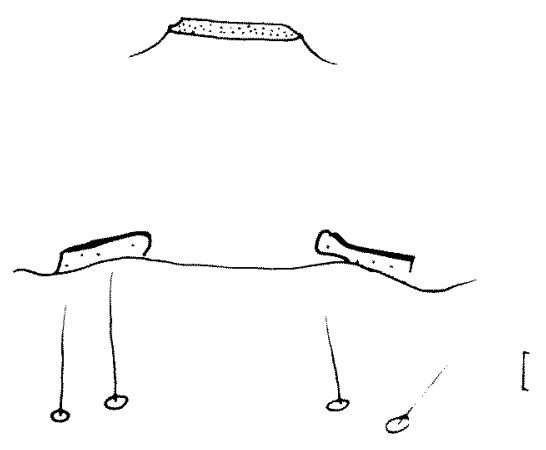

Figures 25-28 Triplectides niveipennis sp. AV 21 larva, WAM 27559: 25, head and thorax dorsal; 26, head ventral; 27, pro-, meso-, and metasternal sclerites; 28, right hind leg posterior. All scale bars $0.1 \mathrm{~mm}$. 
frontoclypeus wider on anterior margin; ventral apotome tapering posteriorly.

Thorax (Figures 20, 21, 23, 25 and 27)

Four to seven metasternal setae each often with small, pale, obvious sclerite at base.

\section{Abdomen}

Gills long, on segments 1 to 5 or 6 dorsally, 2 to 3 or 6 laterally and 2 to 6 or 7 ventrally; lateral line moderately long and pale or dark; tergite 9 very pale, scarcely visible; anal claws each with one dorsal tooth.

\section{Body Length}

About $13 \mathrm{~mm}$.

\section{Case}

Hollowed stick or macrophyte stem.

\section{Early instar larvae}

The extension of the pronotum appears to grow rapidly with later instars so that early instars lack it and third or fourth instar have just a rounded area on the pronotum where the extension will form. These larvae also have a more strongly tapering ventral apotome. Early instar larvae are likely to be confused with early instar larvae of $T$. enthesis as both have the pronotum much darker than the mesonotum.

\section{Remarks}

The long antennae, the occasional division of lateral and posterior metanotal sclerites, and the two-pronged extension on the pronotum are very distinctive of this species and unusual within Triplectides. The case, always a stem or stick hollowed by the larva, is typical of Triplectides.

\section{Material examined}

Triplectides niveipennis (sp. AV 20): Western Australia: Swamp $25 \mathrm{~km}$ NW of Walpole, $100 \mathrm{~m} \mathrm{NW}$ of Beardmore Rd, $34^{\circ} 49^{\prime} \mathrm{S} 116^{\circ} 32^{\prime} \mathrm{E}$, Coll. R. St Clair, 28/10/1997, preserved 3/11/1997, 1; ECU33, Margaret River at Challis on Mowen, 33 55 $46^{\prime \prime} \mathrm{S}$ 11515'51"E, September 1994, Macrophytes, 3 (1, WAM 27558); AV-0507, Margaret River on Great North Rd., 1-2 September 1985, M.S. Harvey and T.J. Doeg, 2.

Reared specimens: AV-5697, Swamp $25 \mathrm{~km} \mathrm{NW}$ of Walpole, $100 \mathrm{~m}$ NW of Beardmore Rd., $34^{\circ} 49^{\prime} \mathrm{S}$ $116^{\circ} 32^{\prime} \mathrm{E}$, Coll. R. St Clair, 28/10/1997, $1 \delta^{\circ}$, locality data lost, Coll. R. St Clair, October 1997, 1 ठ .

Triplectides niveipennis (sp. AV 21): Swamp $25 \mathrm{~km}$ NW of Walpole, $34^{\circ} 49^{\prime} \mathrm{S} 116^{\circ} 32^{\prime} \mathrm{E}$, Coll. R. St Clair, 28/10/1997, preserved 3/11/1997, 3; AV-5649, Swamp near Finlay Brook, $20 \mathrm{~km}$ S of Jarrahdale, 30 August 1985, M.S. Harvey and T.J. Doeg, 2; AV-
0504, Margaret River on Great North Rd, 1-2 September 1985, M.S. Harvey and T.J. Doeg, 3; AV0500, $2 \mathrm{~km} \mathrm{E}$ of Grimwade, 31 August - 1 September 1985, M.S. Harvey and T.J. Doeg, 3; AV0501, St John's Brook 2 km E of Cundinup, 1 Sep, 1985, M.S. Harvey and T.J. Doeg, 5; AV-0506, Barrabup Rd NW of Nannup, temporary pool, 1 September 1985, M.S. Harvey and T.J. Doeg, 1; 3 AV-0503, Hamilton River 11 km WNW of Collie, 31 August 1985, M.S. Harvey and T.J. Doeg; AV-0540, Dillon Brook North Dandalup, Coll. S. Bunn, 31 August 1981, 10 early instars, AV-0509, 22 early instars, station 10 drift sample, 1810-2010 hrs, AV0547, 30 July 1981, 26 early instars; ECU43, Headwater reach of Ludlow River, $33^{\circ} 43^{\prime} 47^{\prime \prime} \mathrm{S}$ $115^{\circ} 27^{\prime} 07^{\prime \prime}$, September 1994, Macrophytes, 7 (1, WAM 27559); ECU33, Margaret $R$ at Challis on Mowen, 335' $46^{\prime \prime} \mathrm{S} 115^{\circ} 15^{\prime} 51^{\prime \prime E}, 28$ September 1994, Macrophytes, 2; ECU34, Margaret River at River Road, 36⒌ $6^{\prime} 35^{\prime \prime} \mathrm{S} 115^{\circ} 06^{\prime} 59^{\prime \prime} \mathrm{E}$, September 1994, Macrophytes, 2; ECU29, Scott River at Milyeannup Road, 34\%17'54"S 115²3'54"E, 14 September 1995, Channel, 3; MUR02, Death Adder Creek, 32 08'10"S $116^{\circ} 10^{\prime} 36^{\prime \prime} \mathrm{E}, 5$ September 1994, Macrophytes, 6, Macrophytes, 28 (fourth instar? With very slight projections) Channel, 3; MUR04, Wungong Brook, $32^{\circ} 18^{\prime} 47^{\prime \prime S} 116^{\circ} 11^{\prime} 05^{\prime \prime} \mathrm{E}, 5$ September 1994, Macrophytes, 2; MUR06, Serpentine River, $32^{\circ} 30^{\prime} 31^{\prime \prime S} 116^{\circ} 17^{\prime} 25^{\prime \prime} \mathrm{E}, 6$ September 1994, Organics, 1; MUR10, Yarragill Brook, 3249'56"S 116 $12^{\prime} 10^{\prime \prime} \mathrm{E}$, 8 September 1994, Riffle, 1, Channel, 2; MUR20,

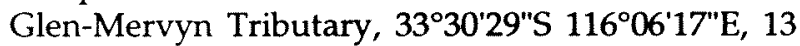
September 1994, Organics, 8; MUR21, Ferguson River Tributary, 3327'03"S 115'56'24"E, 13 September 1994, Channel, 1, Organics, 8 (few with long processes); MUR23, Harvey River at Hoffmans Mill, 3304'41"S 116 06'56"E, 9 September 1994, 3, Channel, 1; MUR30, Dale River, 32 $20^{\prime} 40^{\prime \prime} S$ $116^{\circ} 28^{\prime} 51^{\prime \prime E}$, September 1994, Macrophytes, 1; UWA09, Dudijup Creek on Whim Landing Road, $34^{\circ} 07^{\prime} 55^{\prime \prime S} 116^{\circ} 14^{\prime} 40^{\prime \prime} \mathrm{E}, 14$ October 1994, Macrophytes, 5; Channel, 4; UWA14, Quinninup Brook at Sutton Road, 34 $27^{\circ} 27^{\prime \prime S} 116^{\circ} 15^{\prime} 20^{\prime \prime}$, 13 October 1994, Macrophytes, 3; UWA15, Shannon River Curtin 4 Road, 34 34'12"S 116 $25^{\circ} 49^{\prime \prime} \mathrm{E}, 10$ October 1994, Macrophytes, 1; UWA22, Tributary of Weld River, $34^{\circ} 41^{\prime} 23^{\prime \prime} \mathrm{S} 11^{\circ} 31^{\prime} 15^{\prime \prime} \mathrm{E}, 9$ October 1994, Macrophytes, 1; UWA24, Deep River at Weld

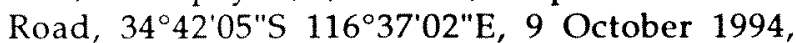
Organics, 1; UWA25, Deep River at Bevan Road, 34.35'36"S 116 33'06"E, 9 October 1994, Macrophytes, 3; UWA29, Walpole River off Plain Road, 34 $57^{\circ} 40^{\prime \prime} \mathrm{S} 116^{\circ} 42^{\prime} 17^{\prime \prime} \mathrm{E}, 8$ October 1994, Macrophytes, 5; UWA30, Nile Creek at Break Road, $34^{\circ} 50^{\prime} 41^{\prime \prime} S 117^{\circ} 02^{\prime} 37^{\prime \prime} E, 29$ September 1994, Macrophytes, 2 (one in Notoperata style case); UWA32, Styx River, $0.5 \mathrm{~km}$ up from Styx Road, $34^{\circ} 52^{\prime} 57^{\prime \prime S} 117^{\circ} 08^{\prime} 21^{\prime \prime E}, 27$ September 1994, Macrophytes, 1; UWA34, Denmark River at Granite 


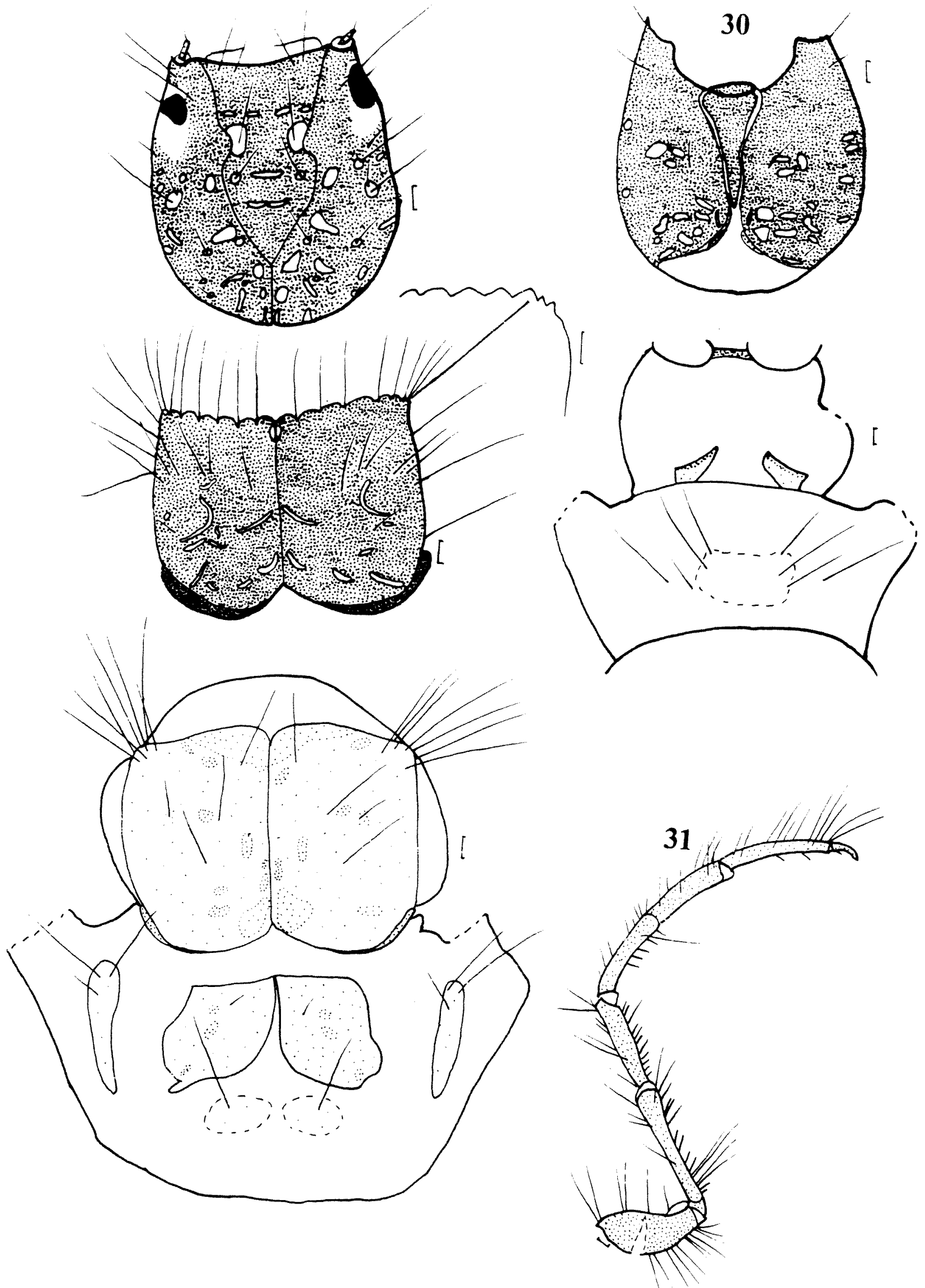

Figures 29-31 Triplectides enthesis larva, WAM 27560: 29, head and thorax dorsal; 30, head and thorax ventral; 31, right hind leg posterior. All scale bars $0.1 \mathrm{~mm}$. 
Road, $34^{\circ} 49^{\prime} 47^{\prime \prime} \mathrm{S} 117^{\circ} 15^{\prime} 02^{\prime \prime} \mathrm{E}, 28$ September 1994, Macrophytes, 2; UWA40, Gaalgegup Creek at Walshpool Road Bridge, 34 35'28'S 117 55'42"E, 23 September 1994, Macrophytes, 8.

Reared specimens: Swamp $25 \mathrm{~km}$ NW of Walpole, $100 \mathrm{~m}$ NW of Beardmore Rd., 34 $4^{\circ} 9^{\prime} \mathrm{S} 116^{\circ} 32^{\prime} \mathrm{E}$ Coll. R. St Clair 28 October 1997, 2 of (one lodged in the Museum of Victoria, AV-5696), \& 1 WAM 27556; Dammed Creek $11 \mathrm{~km}$ WNW of Collie, 33⒈'S $116^{\circ} 02^{\prime} \mathrm{E}$, Coll R. St Clair, 30 October 19971 o , 1 q (lodged in the Museum of Victoria, AV-5695) and 1 i WAM 27557.

\section{Habitat and Distribution}

Permanent still and flowing waters in southwest Western Australia (Figure 34). This species inhabits forest streams or streams in more open habitat. It seems to tolerate warmer waters than Triplectides enthesis and still waters.

\section{Triplectides enthesis Neboiss Larva}

Figures 29-31, 33

\section{Diagnosis}

The ventral apotome tapers strongly (Figure 30); the pronotal anterior margin is only slightly scalloped (Figure 29); the pronotal anterolateral corners are only slightly elongate and angled or scooped laterally (Figure 29); the mesonotum is much paler than the pronotum (Figure 29); the metasternum has a very pale, moderately large, central sclerite (Figure 30).

\section{Description}

Head (Figures 29 and 30)

Width measured across, and including, the eyes $0.82 \mathrm{~mm}$. Red-brown with pale spots; antennae about one eighth length of frontoclypeus on anterior margin; ventral apotome tapering to point.

\section{Thorax (Figures 29 and 30)}

Pronotum red-brown with pale elongate spots; mesonotum much paler than pronotum; metanotal sclerites very pale; about 10 metasternal setae; legs fairly uniform in colour (Figure 31).

\section{Abdomen}

Gills single filaments dorsally on segments 2 to 6 , ventrally on segments 3 to 6 , segment 3 only laterally; tergite 9 extremely pale, not visible, with 6 long setae; each anal claw with three dorsal teeth.

\section{Body Length \\ About $8 \mathrm{~mm}$.}

Case

Whole stick.

\section{Early instar larvae}

These are likely to be confused with early instar larvae of $T$. niveipennis as both have the pronotum much darker than the mesonotum. The pronotal processes of $T$. niveipennis are very short or even absent in fourth instar and the larvae are then indistinguishable from $T$. enthesis early instars

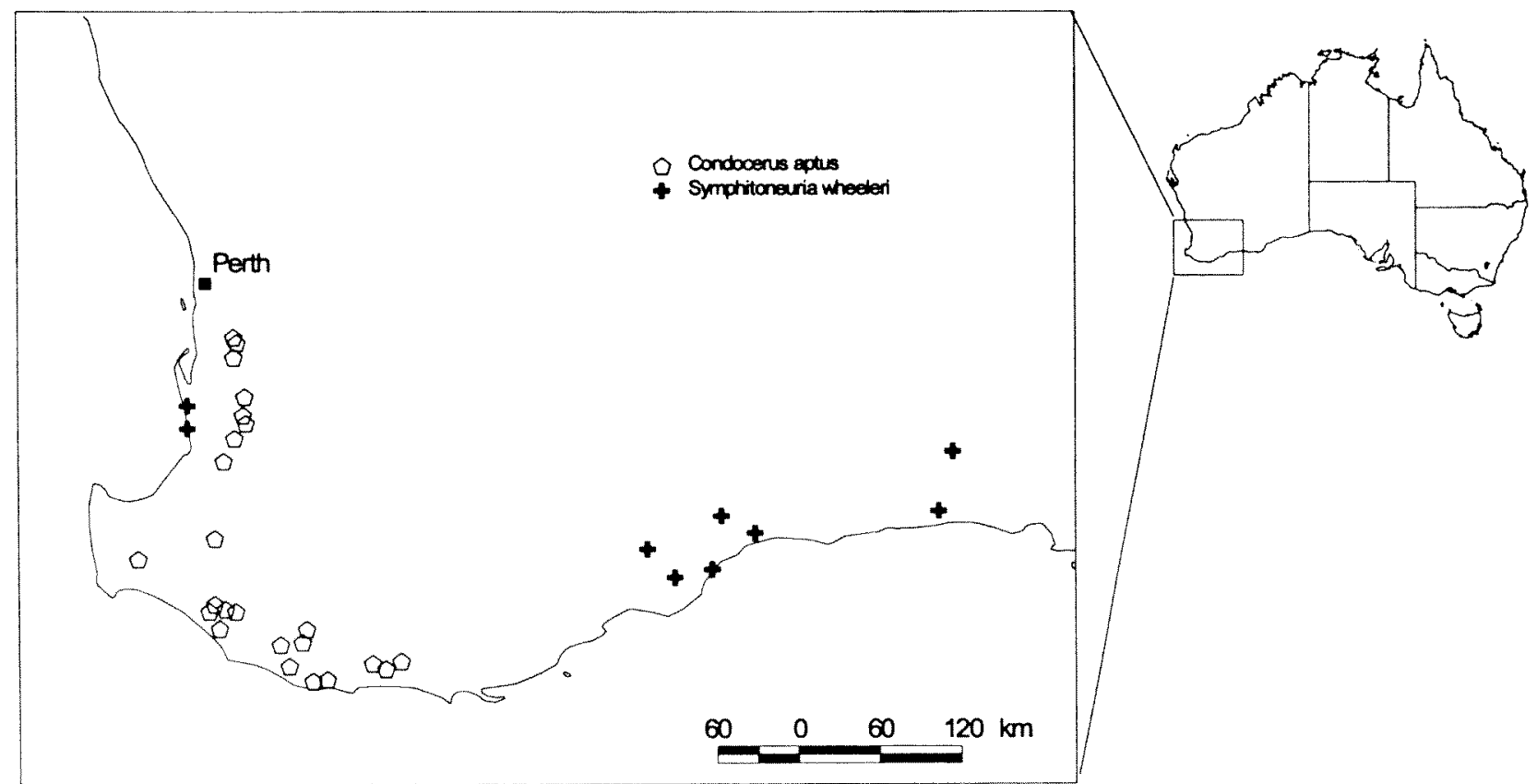

Figure 32 Map showing distribution of specimens of Condocerus aptus and Symphitoneuria wheeleri examined for this study, not including the specimen of $S$. wheeleri from South Australia. 


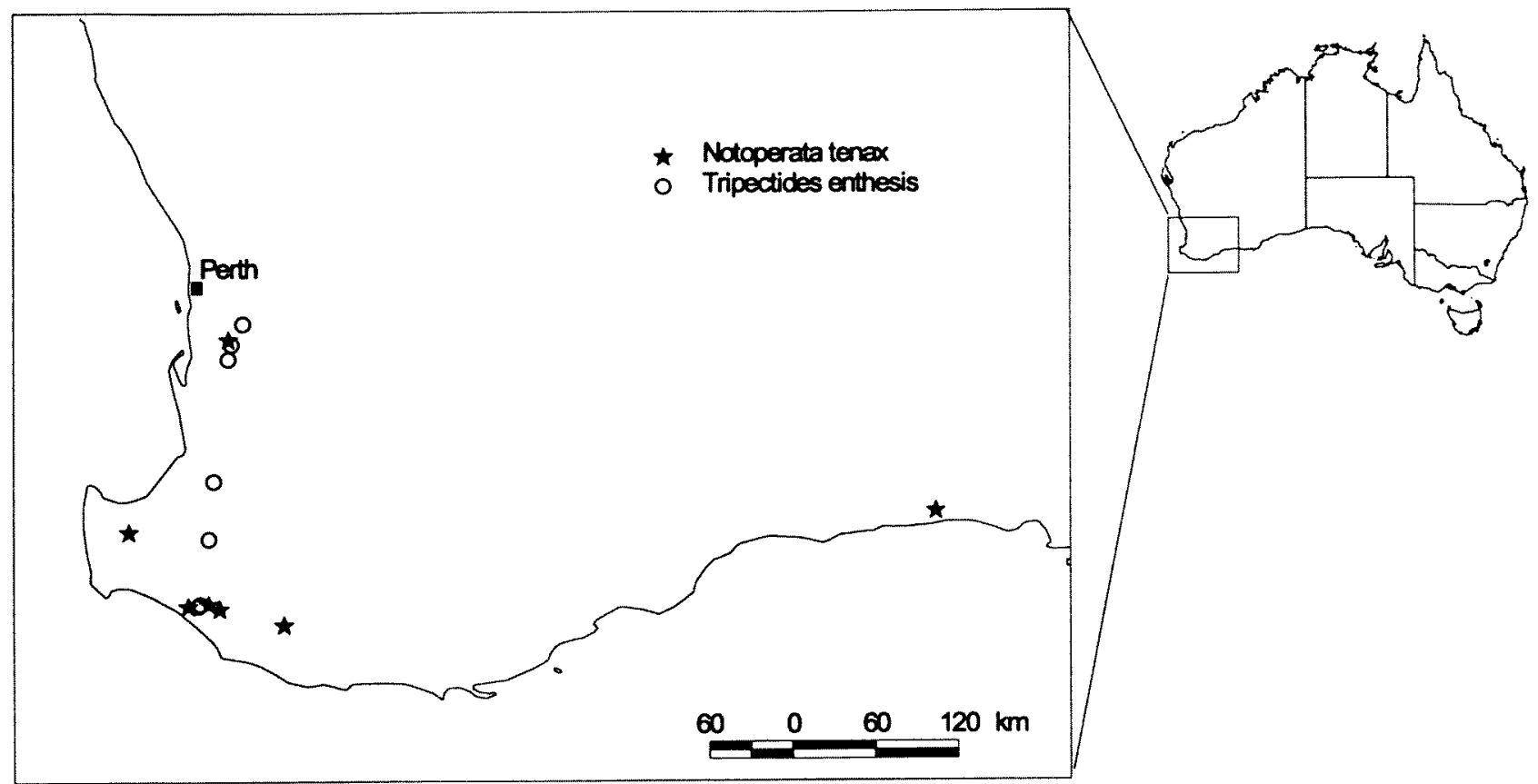

Figure 33 Map showing distribution of specimens of Notoperata tenax and Triplectides enthesis examined for this study, not including the specimen of T. enthesis from the North.

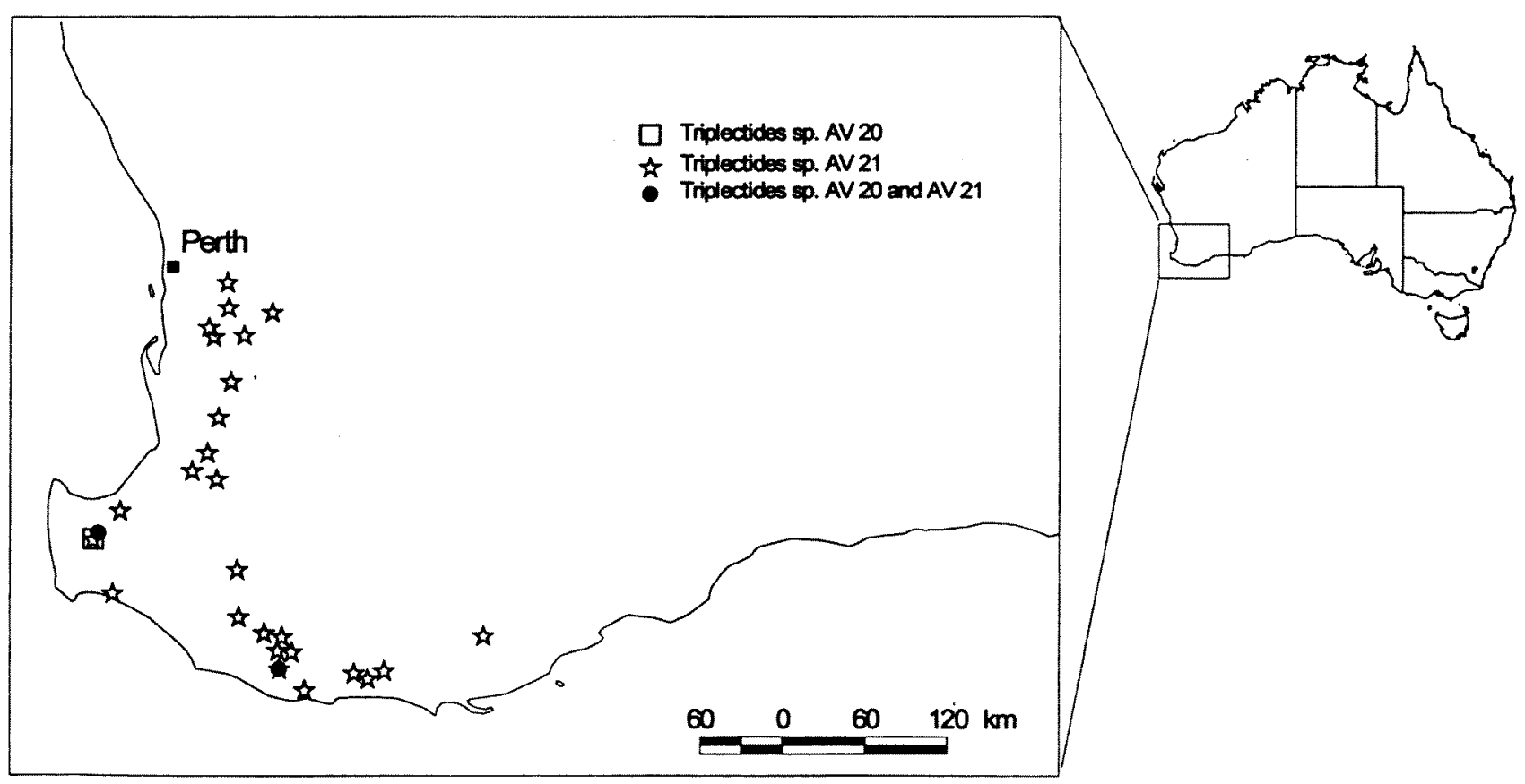

Figure 34 Map showing distribution of specimens of Triplectides niveipennis sp AV 20 and Triplectides niveipennis sp AV 21 examined for this study.

unless the sclerite on the metasternum is apparent.

\section{Remarks}

Larvae of this species are very similar to those of T. proximus from eastern Australia and, apart from the metasternal sclerite, both fit the above diagnosis.

\section{Material examined}

Western Australia: AV-0541, Carey Brook $20 \mathrm{~km}$ W of Pemberton, 26 November 1978, Coll A. Neboiss, 1; AV-0542, Waterfall Gully, Jarrahdale, 18 May 1981 Coll. S. Bunn 1; AV-0543, Seldom Seen Brook, Coll. S. Bunn, 6 October 1982, Station 7, 1, AV-0544, 14 June 1982, 5 early instar, AV-0545, 1 April 1982, 1; AV-0546, Little Dandalup Creek, 
North Dandalup at Torrens Road Bridge, 12 May 1981; MUR12, Little Dandelup River, 32'35'31"S $116^{\circ} 01^{\prime} 34^{\prime \prime E}, 7$ September 1994, Macrophytes, 1;

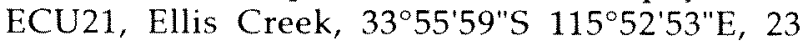
September 1994, 1, WAM 27560; Beedelup Brook, $34^{\circ} 22^{\prime} 50^{\prime \prime} \mathrm{S} 115^{\circ} 55^{\prime} 16^{\prime \prime} \mathrm{E}$. Slow flow headwater stream, Coll. K Trayler. June 1993; Millstream, slow spring-fed channel, $21^{\circ} 45^{\prime} \mathrm{S} 117^{\circ} 00^{\prime} \mathrm{E}$, Coll. L. Charlton.

\section{Habitat and Distribution}

This species is restricted to cool, permanently flowing streams in forested areas (Figure 33). The record from Millstream in northwest Western Australia is very odd, but as it is from a spring-fed channel, this may be from a relict population in cool water.

\section{ACKNOWLEDGEMENTS}

The association of Notoperata tenax was made by Dr. Stuart Bunn. A large amount of material was collected in WA as part of the Monitoring River Health Program and the funding for the Taxonomy Project within this Program enabled examination of this material, both funded by LWRRDC. Drs. Stuart Halse, Jenny Davis, Pierre Horwitz, and Don Edward are thanked for access to this material.
Specimens for rearing and association of Triplectides niveipennis were collected under permit number SF002275 from CALM. Collections in National Parks were acquired with permit number NE001750 and exported to Victoria for rearing and examination under permit number EA002989. Fiona Wells is thanked for providing the distribution maps. The reviewers, Drs. John Morse and Alice Wells, are thanked for very helpful comments.

\section{REFERENCES}

Morse, J.C., and Neboiss, A. (1982). Triplectides of Australia (Insecta: Trichoptera: Leptoceridae). Memoirs of the National Museum of Victoria 43: 61-98.

Neboiss, A. (1982). The Caddis-flies (Trichoptera) of South-Western Australia. Australian Journal of Zoology 30: 271-325.

St Clair, R.M. (1994). Some larval Leptoceridae (Trichoptera) from South-eastern Australia. Records of the Australian Museum 46: 171-226.

St Clair, R.M. (2000). Preliminary keys for the identification of Australian caddisfly larvae of the family Leptoceridae. Identification Guide No. 27. ISBN 1876144289 . Cooperative Research Centre for Freshwater Ecology, Albury.

Manuscript received 18 December 2000; accepted 24 October 2001. 